\title{
Araştırma Makalesi/Research Article (Original Paper) \\ Van İlinde Satılmakta Olan Yaş ve Kuru Üzümler İle Salamura Asma Yapraklarında Pestisit Kalıntı Miktarlarının Belirlenmesi
}

\author{
Ruhan İlknur GAZİĞLU ŞENSOY ${ }^{1 *}$, Leyla ERSAYAR ${ }^{2}$, Adnan DOĞAN ${ }^{1}$ \\ ${ }^{1}$ Yüzüncü Y1l Üniversitesi Ziraat Fakültesi Bahçe Bitkileri Bölümü, Van, Türkiye \\ ${ }^{2}$ Gıda, Tarım ve Hayvancılık Bakanlığı, Van İl Gıda Laboratuvarı, Van, Türkiye \\ *eposta: rigazioglu@yyu.edu.tr
}

\begin{abstract}
Özet: Pestisitler, insan ve çevre sağlı̆̆na olan zararları birçok bilimsel çalışma ile ortaya konulmuş olmasına rağmen, tüm dünyada ve ülkemizde, gün geçtikçe daha fazla yaygınlaşmakta olan bitki koruma ürünleridir. Bitki koruma ürünlerinin prosedüre uygun olmayan miktar ve zamanlarda kullanımı ekolojik dengede ve tarım ürünlerimizde pek çok sıkıntıya yol açmaktadır. Beslenmeden, tekstil ürünlerine kadar birçok alanda insan yaşamının vazgeçilmezi olan bitkisel ürünler aynı zamanda iç ve dış ticarette de büyük önem taşımaktadır. Ancak yetiştirme ya da depolama aşamalarında kullanılan pestisit miktarlarının kabul edilebilir aralığın üstünde olduğunun belirlendiği durumlarda, ihracata yönelik üretilmiş ürünler kabul görmeyerek, sınırdan geri dönmesine neden olabilmektedir. Bu çalışma ile Van yöresinde satılıyor olmakla beraber, temelde ülkemizin üzüm üreticisi olarak kabul edilen, Manisa, Kilis, Adıyaman- Besni, Siirt, Tokat, Balıkesir, Adana, Mersin gibi farklı yörelerinden gelmiş̧ olan hatta sınır ticareti yaptığımız, ülkelerden ithal ettiğimiz yaş ve kuru üzümler ile salamura asma yapraklarına ait örneklerde bulunan pestisit kalıntı miktarlarının, ürünün tüketiciye ulaştı̆̆ dönemlerde belirlenmesi amaçlanmış ve mevcut durum ortaya konulmaya çalışılmıştır. Pestisit analizlerinde, uluslararası geçerliliği bulunan AOAC 2007.01 metodu kullanılmış ve her bir örnek için 250 farklı pestisitin taraması gerçekleştirilmiştir. Sofralık üzümlerde ele alınmış olan 16 örneğin tamamında, 30 farklı pestisite ait kalıntı tespit edilmiş, hatta yasak olmasına rağmen kullanılmış pestisitlerin bulunduğu görülmüştür. Kurutulmuş üzümlerde ise 10 farklı pestisit belirlenmiş, fakat bu konuda ulusal ya da uluslararası bir standart aralık değerine ulaşılamadığından, sonuçlar zarar eşik değerleri bağlamında mukayeseli olarak değerlendirilememiştir. Salamura asma yapraklarında, şahsi tüketim için yapılmış olan salamuraların yanı sıra, ticari olarak markalı ya da markasız satışı yapılan salamura yapraklarında da bir dizi analiz ve gözlemler yapılmış, sonuç olarak ticari bir marka olarak marketlerde satışı yapılmakta olan bir örnek dışında, pestisit kalıntısına rastlanmamıştır.
\end{abstract}

Anahtar kelimeler: Kalıntı, Kuru üzüm, Pestisit, Salamura asma yaprağı, Yaş üzüm

\section{Determination of Pesticide Residue Amounts in Fresh Grapes, Raisins and Pickled Grape Leaves Sold in Van Province}

\begin{abstract}
Pesticides, although with many scientific studies have demonstrated that their damages to the environment and human health all over the world and in our country every day, are being more widespread plant protection products. The residues found in agricultural products bearing great importance in domestic and foreign trade can cause refusal of the products from border from time to time in the acceptance of our export products when they are detected in the range above the acceptable ratios. The present study tried to put the current situation and intended to determine in the amount of pesticide residues found in the samples of fresh grape, raisin, and brined vine leaves that are sold in the Van region and came from different regions, basically accepted as a grape producer in the country, such as Manisa, Kilis, Adıyaman- Besni, Siirt, Tokat, Balıkesir, Adana or Mersin, and even cross-border trade. Internationally recognized AOAC 2007.01 method was used in the pesticide analysis and 250 different pesticides were screened for each sample. In all 16 studied samples, 30 different pesticide residues were detected although the amounts and the resulting active substances of them were different, and it was also detected that some forbidden pesticides were used. Results were evaluated based on damage and allowed range given in Turkish Food Codex and the specified EU MRLs (Maximum Residue Limit) standards. 10 different pesticides were identified in the raisin, but there was no national or international standard range available, so the results could not be considered in the context of comparative damage threshold. A series
\end{abstract}


observations and analysis was made in the brined vine leaves either home-made or the branded or unbranded commercial ones, and out of a commercial sample no pesticide residue was detected in the samples. Because there was no determined limit for the brined vine leaves, the comparisons were made on fresh vine standards, and 5 different pesticides were identified and found to be over the allowable range except one. It is thought that this study will be a reference for more specific studies that are planned to be implemented for some pesticide use in certain regions. Furthermore, this study is the first study conducted on the subject in the region. In the study the different grape products used and implementation and advice on what to do about pesticide residues were revealed.

Keywords: Fresh grapes, Pesticides, Pickled grape leaves, Raisins, Residues

\section{Giriş}

Pestisitler, tüm dünyada ve ülkemizde, gün geçtikçe daha fazla yaygınlaşmakta olan bitki koruma ilaçlarıdır. Bitkilerde hastalık ve zararlıların olumsuz etkilerine karşı korunması amacıyla kullanılmakta olan pestisitler, başta kanser olmak üzere, insan ve çevre sağlığına olan zararları birçok bilimsel çalışma ile ortaya konulmuştur. İç ve dış ticarette de büyük önem taşıyan bitkisel ürünlerde bulunan kalıntılar, zaman zaman dış ticarette kabul edilen aralığın üstünde bir oranda tespit edildiğinden, ihraç ürünlerimiz kabul görmeyerek, sınırdan geri dönmelerine neden olabilmektedir.

Çalışmanın temel amacı, Van yöresinde satılıyor olmakla beraber, temelde ülkenin üzüm üreticisi olarak kabul edilen, Manisa, Kilis, Adıyaman-Besni, Siirt, Tokat, Balıkesir, Adana, Mersin gibi farklı yörelerinden gelmiş olan hatta sınır ticareti yaptığımız, ülkelerden ithal ettiğimiz yaş ve kuru üzümler ile salamura asma yapraklarına ait örneklerde bulunan; vejetasyon dönemi, kurutma ve depolama gibi dönemlerde kullanılmış olan pestisitlerden kalan kalıntıların, ürünün tüketiciye ulaştığı dönemlerde belirlenmesidir. Böylece tüketilen yaş ve kuru üzümler ile salamura yapraklarının üreticiye ulaştığ dönem itibariyle Türk Gida Kodeksinde ve AB MRLs (Maksimum Residue Limiti) standartlarında belirtilmiş ve izin verilmiş olan zarar aralığında olup olmadığı belirlenirken, aynı zamanda, Ülkenin üzüm yetiştiriciliğinde kullanmış olduğu pestisit oranları ve hangi pestisitlerin kullanıldığı konusunda da örnekleme yapılmış böylece bu çalışma sonucunda, ele alınan ürünlerde bulunan kalıntıların insan ve çevre sağlığına ciddi manada zarar verecek seviyede olup olmadığı da ortaya konulmuştur. Çalışmayla farklı bölgelerde yetiştirilmiş ve Van yöresinde satılmakta olan yaş ve kuru üzümler ile salamura asma yapraklarının pestisit düzeylerinin belirlenmiş ve pestisit düzeylerinin kabul edilebilir aralık dahilinde olup olmadığ 1 tespit edilmiştir.

$\mathrm{Bu}$ çalışma, daha sonra yapılması planlanan belli yörelerin pestisit kullanım miktarlarına yönelik olarak uygulanacak daha spesifik çalışmalar için de bir basamak teşkil edecektir. Ayrıca bu çalışma, konu itibariyle yörede yapılmış ilk çalışma olacaktır.

Uluslararası Çevre Koruma Ajansı (EPA)'ya göre pestisitler, zirai ürünlere, insanlara veya diğer canlılara zarar verebilecek böcek, haşere, kemirgen, yabani ot, mantar, bakteri ve virüs gibi canlıların olumsuz etkilerini engellemek, hafifletmek, yok etmek ya da kontrol altında tutabilmek için kullanılan her türlü madde veya madde karışımı olarak tanımlamaktadır.

Pestisitler, yapı olarak canlı organizmaları yok etmek veya işlevlerini yavaşlatmak üzere geliştirildiği ve etki alanları yalnızca hedef organizma ile sınırlı kalmadığı için doğal olarak insanlar ve hayvanlar üzerinde istenmeyen sağlık sorunlarına neden olabilmekte ve ayrıca çevre üzerinde de olumsuz etkiler bırakabilmektedir. Öte yandan, pestisitler potansiyel hastalık yapıcı organizmalar, böcekler, yabani otlar vb. istenmeyen canlıların etkilerini durdurması ve zirai ürünlerin verimini arttırmaları nedeniyle halen yaygın olarak kullanılmaktadır. Pestisitlerin faydaları ve zararları arasında dengenin sağlanabilmesi için bu ürünlerin izin verilen limitler dâhilinde, bilinçli ve doğru kullanımı son derece önemlidir.

Ülkemiz dünyada üzüm üretimi açısından önemli konuma sahiptir. Ancak kurutmalık üzüm İhracatı açısından istenilen düzeyde iken, sofralık üzüm ihracatı düşük orandadır. Yaş üzüm ihracatında yaşanan sorunların başında ise pestisit kalıntısı gelmektedir. Bu durum, özellikle Almanya'da Greenpeace tarafından hazırlanan Pestisitsiz Gıda Rehberinde ülkemizden Almanya'ya ihraç edilen ürünler içerisinde üzümün tehlikeli, riskli ve sakıncalı ürünler listesinde ilk sıralarda yer almış olması durumun ciddiyetini göstermektedir (Anonim 2012). 


\section{R.İ. GAZİOĞLU ŞENSOY, L. ERSAYAR, A. DOĞAN}

Pestisitlerin çevre, sağlık ve ekonomik açıdan getirebilecekleri olumsuzluklar, başta ABD olmak üzere, gelişmiş ülkelerde oldukça ciddi bir şekilde ele alınmakta, tüketilecek tarım ürünleri sürekli olarak denetlemeye tabi tutulmaktadır. Ülkemizin $A B$ ile müzakere ve uyum sürecine başlaması ile birlikte, çevre ve halk sağlığının korunması ve standartlarımızın bu ülkeler seviyesine çıkartılması, pestisitlerin çok bilinçli ve kontrollü kullanılmasının gerekliliği konularında çalışmalar daha önemli görülmeye başlanmıştır. Tarımsal amaçlı kullanılan pestisitlerin çevrede ve gıdalarda oluşturacağı kalıntılar halk sağlığı açısından önemli sakıncalara neden olmaktadır. Özellikle günlük kabul edilebilir limitlerin üzerinde bulunan pestisit kalıntı miktarları, İnsanlarda akut ve kronik zehirlenmeler, tetratojenik, mutajenik ve kanserojenik etkiler gibi birtakım ciddi sağlık problemlerine yol açabilmektedir (Çiftçioğlu ve Issa 2006). Pestisit kalıntıları, deri hastalıkları, akciğer hastalıkları, hemapoietik sistem hastalıkları, bağışıklık sistemi hastalıkları, sindirim sistemi hastalıkları, böbrek ve idrar yolu hastalıkları ile başta düşük, düşük doğum ağırlığı, toksemi ve postpartum kanama olmak üzere birçok kadın üreme sistemi hastalıklarına yol açmaktadır (Güler ve Çobanoğlu 1994).

Üzüme uygulanan çeşitli yıkama koşullarının, chlorpyrifos ethyl, acetamiprid ve penconazole içeren üç farklı pestisitin kalıntılarının uzaklaştııılmasındaki etkilerinin incelendiği çalışma sonucunda, üç pestisitin de kalıntı seviyeleri, yıkama suyu sıcaklığının düşürülmesi ile azalırken, kombine uygulamaların her biri içinde, 40 ve $50{ }^{\circ} \mathrm{C}$ ile karşılaştırıldığında 10,20 ve $30{ }^{\circ} \mathrm{C}$ 'de daha düşük pestisit kalıntı değerleri elde edilmiştir. Buna ek olarak, bütün sıcaklıklarda, üzüm örneklerinden chlorpyrifos ethyln kalıntısının uzaklaştırılmasında, 4 dakikalık daldırma süresinin, 2 ve 3 dakikalık daldırma süreleri kadar etkili olmadığı bildirilmiştir (Akyıldız ve ark. 2013).

Yoğun bir şekilde ve bilinçsiz kullanılan kimyasal pestisitler, sadece insan sağlığını etkilemekle (karsinojen, mutajen ve teratojen) birlikte, bitki ve hayvan türlerinin yok olmasına ve yer altı sularına karışarak hedef alınmayan diğer organizmaların etkilenmesine neden olmaktadır. Hatta ekolojik dengenin sağlanmasında çok kritik rol oynayan birtakım canlıların yok edilmesiyle denge, daha önce sorun teşkil etmeyen zararlıların lehine değişerek, ekonomik zararlı haline gelmelerine neden olabilmektedir (Topuz 2005).

Türkiye yaş meyve-sebze ticaretinin büyük kısmını AB ülkelerine gerçekleştirmektedir. AB gibi gelişmiş ülke veya ülke gruplarında tüketici bilinci gelişmiş düzeydedir. $\mathrm{Bu}$ nedenle tüketiciler söz konusu ürünlerin bazı özellik ve standartlara sahip olmasını istemektedirler. Ülkemiz için meyve-sebze üretiminde pestisit uygulamaları dikkatle takip edilmesi ve uygulanması gereken konulardandır. Uzun bir zaman diliminde derim yapılan ürünler için derim öncesi zaman aralığını sürekli olarak göz önünde bulunduran bir bitki koruma planı olmalı ve bu programdan ödün verilmemelidir (Özdemir 2008).

İzmir semt pazarlarından farklı satıcılardan temin edilen ve Manisa ilinin Salihli ve Turgutlu ilçelerinde yetiştirildiği ve kurutulduğu tespit edilen toplam 11 adet kuru üzüm örneklerinde tespit edilen pestisitlerin Türk Gıda Kodeksi ve AB (Avrupa Birliği) MRLs (Maksimum Residue Limiti)'ne göre değerlendirilmesi sonucunda, örneklerin \%27.27'si kalıntısız bulunurken, \%72,73'ü pestisitle bulaşık olduğu bildirilmiştir. Yine semt pazarlarından temin edilmiş olan taze üzüm numunelerinde tespit edilen pestisitler, Türk Gıda Kodeksi ve AB (Avrupa Birliği) MRLs (Maksimum Residue Limiti)'ne göre değerlendirilmiş, \%26,66's1 kalıntısız bulunurken, \%73,33'ü pestisitle bulaşık bulunmuştur (Tatlı 2006).

Tokat yöresinde üretilen salamuralık asma yapraklarında pestisit kalıntı düzeylerinin belirlendiği çalışmada, 11 fungusit ve 12 insektisit etken maddesine rastlanmıştır. Yaprak örneklerinin \% 50,0'sinde pestisit, \% 41,6'sında ise bakır kalıntı miktarları Maksimum Rezidü Limit değerlerinin üzerinde çıkmıştır. Örneklerde Triadimenol, Azoxystrobin ve Metalaxyl kalıntısına daha fazla rastlanmıştır. Asma yaprağ 1 üreticilerinin sistemik pestisit kullanmamaları tavsiye edilmiştir. Ticari firmaların üreticilerden aldıkları yapraklarda kalıntı analizi yaptırmaları ayrıca önerilmiştir (Yanar ve ark. 2015).

Narince üzüm çeşidine (V. vinifera) ait asmalarda yaprak hasat döneminde külleme ve mildiyöye karşı 2 farklı fungusit uygulaması (folpet + triadimenol ve carbendazim + metalaxyl + mancozeb) yapıldığ çalışmada, asma yaprakları, etken maddelerin önerilen bekleme sürelerinin sonunda hasat edilmiştir. Bağlarda kullanılan fungusitlerde, üzüm için önerilen uygulama ve hasat arasında geçmesi gereken sürenin, asma yaprağı için geçerli olmadığı belirlenmiştir. Sonuçta, salamuralık asma yaprağı üretilen bağlarda sistemik fungusit kullanılmaması, kontakt etkili fungusit kullanırken ise dikkat edilmesi önerilmiştir (Cangi ve ark. 2014). 
Konya yöresinde halkın tüketimine sunulan mahalli pazarlar ve marketlerden temin edilen üzüm ve çileklerde pestisit kalıntılarının LC-MS/MS ve GC-MS ile belirlenmesi amacıyla yapılmış olan çalışmada ele alınan yaş üzüm numunelerinde pestisit kalıntısına rastlanmayan ürün, toplam ürünün $\% 38$ 'ini, bir adet pestisit kalıntısı bulunan \%10'unu, 2 adet pestisit kalıntısı bulunan \%20'sini, 3 adet pestisit kalıntıs1 bulunan \%10'unu, 4 adet pestisit kalıntısı bulunan \%11'ini, 5 adet pestisit kalıntısı bulunan \%9'unu, 6 ve 7 adet pestisit kalıntısı bulunan \%2'sini oluşturmuştur (Ersoy ve ark. 2011).

İtalya'da üzüm ve şarap örneklerinde, pestisit kalıntısı belirlemek amacıyla 1998 ve 1999 yıllarında yapılan bir çalışmada, üzüm örneklerinde yıllara göre sırasıyla \%2,1-6,1 arasında kalıntı bulunurken, şaraplarda kalıntıya rastlanmamıştır (Cabras ve Conte 2001).

\section{Materyal ve Yöntem}

\section{Materyal}

Bu çalışma kapsamında, Van İli ve çevresinde satılmakta olan Van, Siirt, Adıyaman, Kilis, Manisa, Gaziantep, gibi illerimiz ile ithalat yoluyla İran'dan (kuru üzüm) getirilmiş olan 16 adet taze ve 15 adet kuru üzüm örneği ile 15 farklı salamura asma yaprağında olmak üzere, toplam 45 örnekte pestisit taraması gerçekleştirilmiştir. 250 farklı pestisitin tarandığı çalışmada, kullanılmış olan pestisitlerin etken maddesinin belirlenmesiyle birlikte, kalıntının hangi amaçla kullanılan tarımsal ilaçlara ait olduğu da tespit edilmiştir.

\section{Yöntem}

Pestisit analizlerinde AOAC 2007.01 metodu kullanılmıştır. Homojenize edilmiş örnekten $15 \mathrm{~g}$ alınarak, 50 ml'lik santrifüj tüpüne aktarılmış, üzerine Kit A (QuECHERS Extraction Salt $6 \mathrm{MgSO}$, 1,5 gr $\mathrm{NaOAc}$ ) eklenmiş ve aynı tüpün üzerine $15 \mathrm{ml} \% 1$ asetik asit içeren asetonitril çözeltisinden konulmuştur. Tüpün kapağı iyice kapatılarak 1 dakika kuvvetlice çalkalandıktan sonra, tüp, $1 \mathrm{dk}$. boyunca $5000 \mathrm{rpm}$ de santrifüj edilmiştir. Üst fazdan $10 \mathrm{ml}$ 'lik tüp'e $6 \mathrm{ml}$ alınarak, üzerine Kit B (QuECHERS clean up kit $1200 \mathrm{mg} \mathrm{MgSO} 4+400$ mg PSA) dikkatlice aktarılmıştır. Tüpün ağzı sıkıca kapatılarak 30 sn kuvvetlice çalkalanmış, $5000 \mathrm{rpm}$ de $1 \mathrm{dk}$. santrifüj edilmiştir. LC-MS-MS analizi için $0.2 \mu \mathrm{m}$ 'lik viale alındıktan sonra filtreden geçirilen ekstrakttan viale $0.5 \mathrm{ml}$ konulmuş, üzerine $475 \mu 1$ suda hazırlanmış $10.57 \mathrm{mM}$ amonyum format çözeltisi ve $25 \mu 1$ asetonitril ilave edilmiştir. Vialin kapağı kapatıldıktan sonra hafifçe çalkalanmış, oto örnekleyiciye yerleştirilmiş ve enjeksiyon yapılmıştır. Okumalar, MSMS(LC) (Massspectrometry-Kütle Spektrofotometresi) cihazında yapılmıştır (Anonim 2014). Tespit edilmiş olan pestisit kalıntı miktarları, Türk Gıda Kodeksi, Pestisitlerin Maksimum Kalıntı Yönetmeliği Resmi Gazete 29099-24 Ağustos 2014'e göre yorumlanmıştır.

\section{Bulgular ve Tartışma}

\section{Sofralı Üzümlerde Saptanan Pestisit Değerleri}

Piyasadan temin edilmiş ve yöredeki bağlardan alınmış taze sofralık üzümlerde 250 farklı pestisitin taraması yapılmıştır. Taze üzümlerin tamamında pestisit kalıntısına rastlanırken, bazı örneklerdeki kalıntı miktarları, uluslararası kabul görmüş, bulunabilecek en yüksek kalıntı miktarını ifade eden MRL değerlerine göre karşılaştırıldığında, sınır aralığın altında bulunmuştur. Bazı örneklerdeki kalıntı miktarlarının ise kabul edilebilir aralığın çok üstünde olduğu belirlenmiştir. Sınır aralığın üzerinde miktarlarda belirlenmiş olan kalıntı miktarları, koyu renkli rakamlarla gösterilmiştir (Çizelge 1.). Ayrıca sofralık üzüm analizleri sonucu, yasaklı bulunan ve kesinlikle kullanılmaması gereken İmazapyr ve Cycloate isimli pestisitlerin de 6 örnekte bulunduğu tespit edilmiştir (Çizelge 1.).

İzmir semt pazarlarından farklı satıcılardan temin edilen ve Manisa ilinin Salihli ve Turgutlu ilçelerinde yetiştirildiği belirlenmiş olan taze üzüm numunelerinde tespit edilen pestisitler, Türk Gıda Kodeksi ve $\mathrm{AB}$ (Avrupa Birliği) MRLs (Maksimum Residue Limiti)'ne göre değerlendirilmiş, \%26,66'sı kalıntısız bulunurken, \%73,33'ü pestisitle bulaşık bulunmuştur (Tatl1, 2006). Konya yöresinde halkın tüketimine sunulan mahalli pazarlar ve marketlerden temin edilen üzüm ve çileklerde pestisit kalıntılarının LCMS/MS ve GC-MS ile belirlenmesi amacıyla yapılmış olan çalışmada ele alınan yaş üzüm numunelerinde pestisit kalıntısına rastlanmayan ürün, toplam ürünün $\% 38^{\prime}$ ini, bir adet pestisit kalıntısı bulunan $\% 10$ 'unu, 


\section{R.İ. GAZİOĞLU ŞENSOY, L. ERSAYAR, A. DOĞAN}

2 adet pestisit kalıntısı bulunan \%20'sini, 3 adet pestisit kalıntısı bulunan \%10'unu, 4 adet pestisit kalıntısı bulunan \%11'ini, 5 adet pestisit kalıntısı bulunan \%9'unu, 6 ve 7 adet pestisit kalıntısı bulunan \%2'sini oluşturmuştur (Ersoy ve ark. 2011).

\section{Kuru Üzümlerde Saptanan Pestisit Değerleri}

Piyasadan temin edilen paketli, markalı ya da dökme olarak satılan kuru üzümlere bakıldığında, taze üzümlere göre daha az sayıda pestisitin tespit edildiği görülmektedir. Bu sonuç bizi, kurutma esnasında, birçok pestisit çeşidinde ve miktarlarında azalmaların olabileceği sonucuna götürmektedir (Çizelge 2). Çalışmada ele alınan 16 kuru üzüm numunesinden, 5'inde pestisit kalıntısına rastlanmazken, 11 adet numunede pestisit türü ve kalıntı miktarı örneğe göre değişmekle birlikte, 10 farklı pestisite rastlanmıştır. Ancak kuru üzümün Türk Gıda Kodeksi ve AB MRLs'nde tolerans değerleri ve maksimum kalıntı limitleri de henüz saptanmamış ve belirtilmemiş olması nedeniyle, bulunan pestisitlerin kalıntı miktarları, Türk Gıda Kodeksi ve AB MRLs'ne göre karşılaştırmalı olarak değerlendirilememiştir.

İzmir semt pazarlarından farklı satıcılardan temin edilen ve Manisa ilinin Salihli ve Turgutlu ilçelerinde yetiştirildiği ve kurutulduğu tespit edilen toplam 11 adet kuru üzüm örneklerinin \%27.27'si kalıntısız bulunurken, \%72,73'ünün pestisitle bulaşık olduğu bildirilmiştir (Tatlı 2006). Aynı şekilde bu çalışmada da elde edilmiş olan kalıntı miktarları mukayeseli olarak verilemediği görülmüştür.

\section{Salamura Yapraklarda Saptanan Pestisit Değerleri}

Salamura yaprakların temininde, ticari olarak markalı ve ambalajlı halde satışı yapılan yapraklar ile geleneksel olarak evlerde şahsi kullanım için yapılmış olan salamura yapraklar incelenmiştir. Farklı yöreleri temsil eden salamura yapraklara ait 14 örnekte hiçbir pestisit kalıntısına rastlanmazken, marketten temin edilmiş olan Manisa menşeli ve markalı bir örnekte, pestisit kalıntılarına rastlanmıştır (Çizelge 3). Sonuçlar Türk Gıda Kodeksi Pestisitlerin Maksimum Kalıntı Limitleri Yönetmeliği, Ek:1 İşlenmiş Bitkisel Ürünler, Asma Yaprağı (Anonim, 2016) baz alınarak ilgili MRL değerlerine göre değerlendirilmiştir. Numunede, belirlenmiş olan 5 farklı pestisitten, Metalaxyl dışındakilerin, izin verilen aralığın üstünde olduğu tespit edilmiştir.

Asma yaprăğ Ülkemiz ve Yunanistan dışında ticari bir ürün olarak kullanılmaması nedeniyle, pestisit üreten firmaların bu konuda bir MRL değerleri konusunda ciddi bir çalışmaları bulunmamaktadır. AB ülkelerinde asma yaprağında Kodeks değerlerinin belirlenmesiyle birlikte ülkemiz Gıda, Tarım ve Hayvancılık Bakanlığı da Asma yapraklarında bulunmasına izin verilen MRL değerlerini açıklamıştır (Anonim 2016).

Tokat yöresinde üretilen salamuralık asma yapraklarında pestisit kalıntı düzeylerinin belirlendiği çalışmada, 11 fungusit ve 12 insektisit etken maddesine rastlanmıştır. Yaprak örneklerinin \%50.0' de pestisit, \%41.6'da ise bakır kalıntı miktarları maksimum rezidü limileri değerlerinin üzerinde çıkmıştır. Örneklerde Triadimenol, Azoxystrobin ve Metalaxyl kalıntısına daha fazla rastlanmıştır (Özata 2015). Farklı bir çalışmada ise Narince üzüm çeşidine ( $V$. vinifera) ait asmalarda yaprak hasat döneminde külleme ve mildiyöye karşı 2 farklı fungusit uygulaması (folpet + triadimenol ve carbendazim + metalaxyl + mancozeb) yapıldığı çalışmada, asma yaprakları, etken maddelerin önerilen bekleme sürelerinin sonunda hasat edilmiştir. Bağlarda kullanılan fungusitlerde, üzüm için önerilen uygulama ve hasat arasında geçmesi gereken sürenin, asma yaprağı için geçerli olmadığı belirlenmiştir. Sonuçta, salamuralık asma yaprağı üretilen bağlarda sistemik fungusit kullanılmaması, kontakt etkili fungusit kullanırken ise dikkat edilmesi önerilmiştir (Cangi ve ark. 2014). 
Belirlenmiş Olan Pestisitler

\begin{tabular}{|c|c|c|c|c|c|c|c|c|c|c|c|c|c|c|c|c|}
\hline Çeşitler & $\begin{array}{l}\vec{d} \\
\text { de } \\
\sum^{0}\end{array}$ & 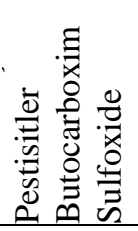 & 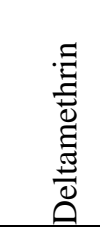 & 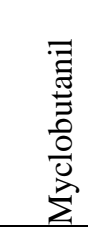 & 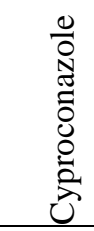 & 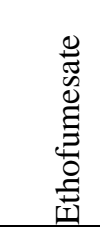 & 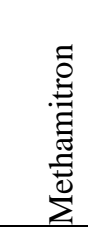 & 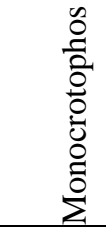 & $\begin{array}{l}\bar{\Xi} \\
. \bar{J} \\
\stackrel{\overrightarrow{0}}{3}\end{array}$ & 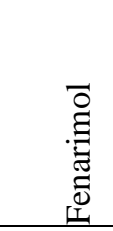 & 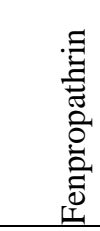 & 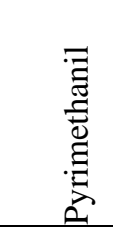 & 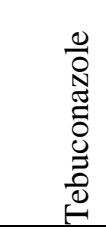 & 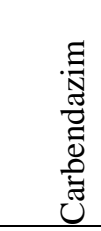 & 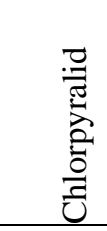 & 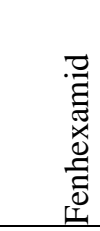 \\
\hline Mrl Değerleri & & - & 50 & 1000 & 5000 & 50 & 100 & 10 & 5000 & 3000 & 10 & 5000 & 500 & 300 & 500 & 5000 \\
\hline Siyah keçimemesi 1 & Erciş & 9.01 & - & - & - & 20.6 & 122 & 421 & - & - & - & - & - & - & - & - \\
\hline Beyaz keçimemesi 1 & Erciş & - & - & - & - & 16.1 & 23.9 & 226 & - & - & - & - & - & - & - & - \\
\hline Beyaz çekirdeksiz & Manisa & 9.01 & - & 363 & 361 & 23.3 & - & - & 1730 & - & - & 1500 & - & - & - & - \\
\hline Koyungözü & Erciş & - & - & - & - & 27.5 & - & 100 & - & - & - & - & - & - & - & - \\
\hline Erciş 1 & Erciş & - & - & - & - & 11.9 & 36.9 & 72.8 & - & - & - & - & - & - & - & - \\
\hline Erciş 2 & Erciş & - & - & - & - & - & 135 & 460 & - & - & - & - & - & - & - & - \\
\hline Siyah keçimemesi 2 & - & - & - & - & 94.8 & 11.8 & 108 & 466 & - & - & - & - & - & - & - & - \\
\hline Beyaz keçimemesi 2 & - & - & - & - & - & 17.5 & 119 & 231 & - & - & - & - & - & - & - & - \\
\hline Redglobe1 & - & 84 & - & 23.5 & - & 10.5 & 16.1 & - & - & - & - & - & - & - & - & - \\
\hline Redglobe 2 & - & - & - & - & - & 14.6 & - & - & - & - & 177 & 479 & - & 84.3 & 541 & 988 \\
\hline Koyungözü & - & 16.2 & - & - & - & 9.03 & 221 & 114 & - & - & - & - & - & - & - & - \\
\hline Sultani Çekirdeksiz 1 & Manisa & - & 11.8 & 9.62 & - & 21.5 & - & - & 69 & - & - & 285 & 128 & - & - & - \\
\hline Beyaz Üzüm & - & 134 & - & - & - & 32.6 & 81 & - & - & 17.3 & - & 254 & 96.9 & - & - & - \\
\hline Siyah Üzüm 1 & - & 16.9 & - & - & - & 13.3 & 73.9 & - & 379 & - & - & - & - & 491 & 3130 & - \\
\hline Siyah Üzüm 2 & - & - & - & - & - & - & - & - & 226 & - & - & - & - & 383 & 2520 & - \\
\hline Sultani Çekirdeksiz 2 & - & 2860 & - & - & - & 23 & - & - & - & - & - & 1610 & - & - & - & - \\
\hline
\end{tabular}




$$
\text { Belirlenmiş Olan Pestisitler }
$$

\begin{tabular}{|c|c|c|c|c|c|c|c|c|c|c|c|c|c|c|c|c|}
\hline Çeşit & 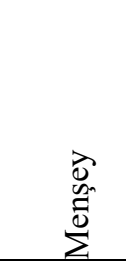 & 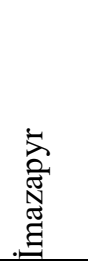 & 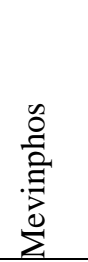 & 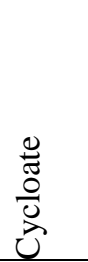 & 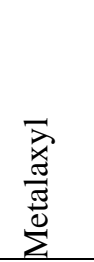 & 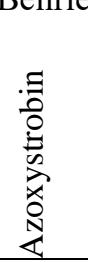 & $\begin{array}{l}\text { О } \\
0 \\
\widetilde{U} \\
0 \\
0 \\
0 \\
0\end{array}$ & \begin{tabular}{l}
$\stackrel{\mathscr{N}}{\mathbb{N}}$ \\
\multirow{\Xi}{*}{} \\
\end{tabular} & 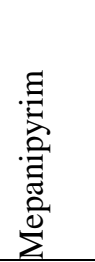 & 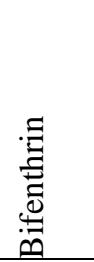 & 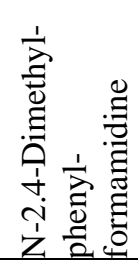 & 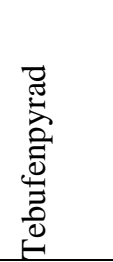 & 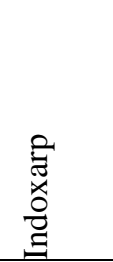 & 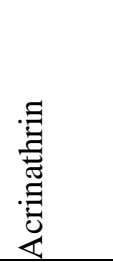 & 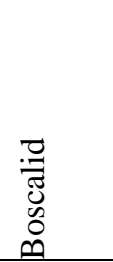 & 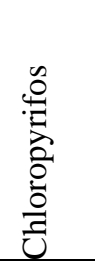 \\
\hline Mrl Değerleri & & - & 50 & 1000 & 5000 & 50 & 100 & 10 & 5000 & 3000 & 10 & 5000 & 500 & 300 & 500 & 5000 \\
\hline Siyah keçimemesi 1 & Erciş & 9.01 & - & - & - & 20.6 & 122 & 421 & - & - & - & - & - & - & - & - \\
\hline Beyaz keçimemesi 1 & Erciş & - & - & - & - & 16.1 & 23.9 & 226 & - & - & - & - & - & - & - & - \\
\hline Beyaz çekirdeksiz & Manisa & 9.01 & - & 363 & 361 & 23.3 & - & - & 1730 & - & - & 1500 & - & - & - & - \\
\hline Koyungözü & Erciş & - & - & - & - & 27.5 & - & 100 & - & - & - & - & - & - & - & - \\
\hline Erciş 1 & Erciş & - & - & - & - & 11.9 & 36.9 & 72.8 & - & - & - & - & - & - & - & - \\
\hline Erciş 2 & Erciş & - & - & - & - & - & 135 & 460 & - & - & - & - & - & - & - & - \\
\hline Siyah keçimemesi 2 & - & - & - & - & 94.8 & 11.8 & 108 & 466 & - & - & - & - & - & - & - & - \\
\hline Beyaz keçimemesi 2 & - & - & - & - & - & 17.5 & 119 & 231 & - & - & - & - & - & - & - & - \\
\hline Redglobe 1 & - & 84 & - & 23.5 & - & 10.5 & 16.1 & - & - & - & - & - & - & - & - & - \\
\hline Redglobe 2 & - & - & - & - & - & 14.6 & - & - & - & - & 177 & 479 & - & 84.3 & 541 & 988 \\
\hline Koyungözü & - & 16.2 & - & - & - & 9.03 & 221 & 114 & - & - & - & - & - & - & - & - \\
\hline Sultani Çekirdeksiz 1 & Manisa & - & 11.8 & 9.62 & - & 21.5 & - & - & 69 & - & - & 285 & 128 & - & - & - \\
\hline Beyaz Üzüm & - & 134 & - & - & - & 32.6 & 81 & - & - & 17.3 & - & 254 & 96.9 & - & - & - \\
\hline Siyah Üzüm 1 & - & 16.9 & - & - & - & 13.3 & 73.9 & - & 379 & - & - & - & - & 491 & 3130 & - \\
\hline Siyah Üzüm 2 & - & - & - & - & - & & - & - & 226 & - & - & - & - & 383 & 2520 & - \\
\hline Sultani Çekirdeksiz 2 & - & 2860 & - & - & - & 23 & - & - & - & - & - & 1610 & - & - & - & - \\
\hline
\end{tabular}

Çizelge 2. Kuru Üzüm Pestisit Kalıntı Miktarları (ppm) 


\begin{tabular}{|c|c|c|c|c|c|c|c|c|c|c|c|}
\hline \multirow[b]{2}{*}{ Çeşit } & \multirow[b]{2}{*}{ 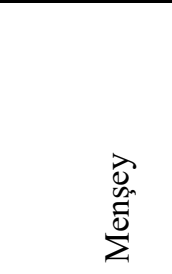 } & \multicolumn{10}{|c|}{ Belirlenmiş Olan Pestisitler } \\
\hline & & 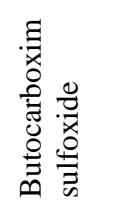 & 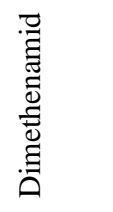 & 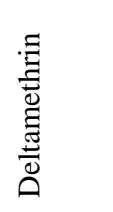 & 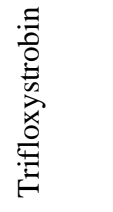 & 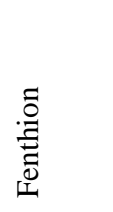 & 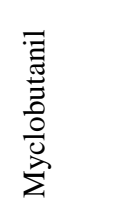 & 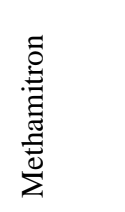 & 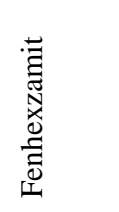 & 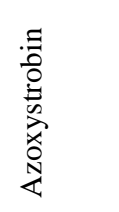 & 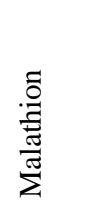 \\
\hline \multicolumn{2}{|l|}{ Mrl Değerleri } & - & - & - & - & - & - & - & - & - & - \\
\hline Sultani Çekirdeksiz 1 & Manisa & 18.20 & 48.7 & - & - & - & - & - & - & - & - \\
\hline Sultani Çekirdeksiz 2 & Manisa & - & - & - & - & - & - & - & - & - & - \\
\hline Sultani Çekirdeksiz 3 & Manisa & 9.07 & - & - & - & - & - & - & - & - & - \\
\hline Sultani Çekirdeksiz 4 & Manisa & 9 & - & - & - & - & - & - & - & 32.8 & - \\
\hline Sultani Çekirdeksiz 5 & Manisa & - & - & - & - & - & - & - & - & - & 164 \\
\hline Sultani Çekirdeksiz 6 & Manisa & - & - & - & - & - & - & 43.4 & - & - & - \\
\hline Siyah Çekirdeksiz & Manisa & - & - & - & - & - & - & - & - & - & - \\
\hline Sultani Çekirdeksiz & Tariş & - & - & - & - & - & - & - & - & - & - \\
\hline Besni 1 & Adiyaman & - & - & 45.5 & 96.9 & - & - & - & - & - & - \\
\hline Besni 2 & Besni & - & - & - & - & 162 & 13 & - & - & - & - \\
\hline Besni 3 & Besni & - & - & 9.34 & 13.2 & 69 & - & - & - & - & - \\
\hline Siyah Çekirdeksiz & Manisa & - & - & - & 10.4 & - & 9.12 & 79.4 & 12.8 & - & - \\
\hline Siyah Çekirdekli (iri meyveli) & Kilis & 9.12 & - & - & - & - & - & - & - & - & - \\
\hline Siyah Çekirdekli (küçük meyveli) & Siirt & - & - & - & - & - & - & - & - & - & - \\
\hline Sultana 1 & İran & 16.6 & - & - & - & - & - & - & - & - & - \\
\hline Sultana 2 & İran & - & - & - & - & - & - & - & - & - & - \\
\hline
\end{tabular}

Çizelge 3. Salamura Yaprak Pestisit Kalıntı Miktarları (ppm)

Çeşit 
R.İ. GAZİĞLU ŞENSOY, L. ERSAYAR, A. DOĞAN

\begin{tabular}{|c|c|c|c|c|c|}
\hline & 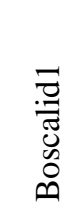 & $\begin{array}{l}\vec{\lambda} \\
\frac{\vec{d}}{\tilde{J}} \\
\sum_{\Sigma}^{\mathbb{d}}\end{array}$ & 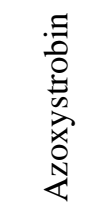 & 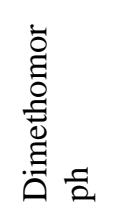 & 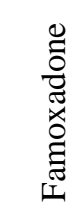 \\
\hline Mrl Değerleri & 10 & 50 & 10 & 10 & 10 \\
\hline Adana 1 (Ev tipi) & - & - & - & - & - \\
\hline Adana 2 (Ev tipi) & - & - & - & - & - \\
\hline Adana 3 (Ev tipi) & - & - & - & - & - \\
\hline Tokat 1 (Ticari Marka)) & - & - & - & - & - \\
\hline Tokat 2 (Ticari Marka) & - & - & - & - & - \\
\hline Tokat 3 (Ev tipi) & - & - & - & - & - \\
\hline Balıkesir (Ticari) & - & - & - & - & - \\
\hline Beytüşşebap (Ev tipi) & - & - & - & - & - \\
\hline Erciş 1 yaprak (Ev tipi) & - & - & - & - & - \\
\hline Erciş 2 yaprak (Ticari) & - & - & - & - & - \\
\hline Hakkari yaprak (Ev tipi) & - & - & - & - & - \\
\hline İzmir yaprak (Ticari) & - & - & - & - & - \\
\hline Şemdinli yaprak (Ev tipi) & - & - & - & - & - \\
\hline Manisa (Ticari) & - & - & - & - & - \\
\hline Manisa (Ticari Marka) & 145 & 11 & 67.2 & 33.5 & 58,1 \\
\hline
\end{tabular}




\section{Sonuç}

Gerek yöreye ait gerekse başka şehirlerimizden getirilerek satışa sunulmuş olan sofralık üzümlerde alınmış olan 16 örneğin tamamında, kalıntı miktarları ve ortaya çıkan etken maddeler farklı olmakla beraber, 30 farklı pestisite ait kalıntı tespit edilmiş, hatta yasak olmasına rağmen kullanılmış pestisitlerin kullanılmış olduğu görülmüştür. Sonuçlar, Türk Gıda Kodeksinde ve AB MRLs (Maksimum Residue Limiti) standartlarında belirtilmiş ve izin verilmiş olan rezidü aralığı baz alınarak değerlendirilmiştir. Kurutulmuş üzümlerde ise taze üzümlere göre daha az sayıda olmakla beraber 10 farklı pestisit belirlenmiş, fakat bu konuda ulusal ya da uluslararası bir standart aralık değerine ulaşılamadığından, sonuçlar zarar eşik değerleri bağlamında mukayeseli olarak değerlendirilememiştir. Toplamda 16 adet olan kuru üzüm numunesinden 5 adedinde kalıntı bulunmadığı görülmüştür. Bu konuda sevindirici olan, ülkemizin en köklü tarımsal kooperatiflerinden biri olan, ürettiği ve ihraç ettiği kuru üzüm ile Türkiye'nin en büyük çekirdeksiz kuru üzüm alıcısı ve ihracatçısı kuruluşu olan Tariş Üzüm Birliği tarafından piyasaya arz edilmiş olan kuru üzümlerde, pestisite rastlanmamış olmasıdır. Salamura asma yapraklarında, kendi evinin kullanımı için yapılmış olan salamuraların yanı sıra, ticari olarak markalı ya da markasız satışı yapılan salamura yapraklarda da bir dizi analiz ve gözlemler yapılmış, sonuç olarak ticari bir marka olarak marketlerde satışı yapılmakta olan bir örnek dışında, pestisit kalıntısına rastlanmamıştır. Numunede, belirlenmiş olan 5 farklı pestisitten, Metalaxyl dışındakilerin, izin verilen aralığın üzerinde olduğu belirlenmiştir.

$\mathrm{Bu}$ çalışma, daha sonra yapılması planlanan belli yörelerin pestisit kullanım miktarlarına yönelik olarak uygulanacak daha spesifik çalışmalar için de bir basamak teşkil edeceği düşünülmektedir. Ayrıca bu çalışma, konu itibariyle yörede yapılmış ilk çalışma olma özelliğindedir.

Pestisit kullanımının ve kalıntı sorununun özellikle taze tüketilen üzümler için genel bir sorun olduğu gözlemlenmiştir. Pestisit kullanımında gerek miktar ve gerekse uygulama zamanında yapılmış olan hatalar, ciddi sağlık sorunlarıyla karşılaşılabilecek düzeyde kalıntı bırakabilmektedir. Bu konuda bir diğer önemli sorun da, ihracata yönelik üretimde yaşamamız muhtemel olan sorunlardır. Özellikle de yasaklı bulunan pestisitlerin tespit edilmiş olması, ya da kullanılabilir pestisitlerin kabul edilebilir düzeyin üzerindeki kalıntı miktarlarının bulunması oldukça ciddiye alınması ve üzerinde titizlikle durulması gereken bir konu olduğu gözden uzak tutulmamalıdır. Ülkemizde ve Dünyada bu yönde çalışmaların çoğaltılması, gerekiyorsa konu hakkında ciddi yaptırımların uygulanması gerekmektedir. Aksi takdirde çeşitli kanser türleri başta olmak üzere, doğumla başlayan birçok anomalinin ve çeşitli sağlık sorunlarının önüne geçilemeyecektir. En önemli ihraç ürünlerimizden biri olan kurutulmuş üzümle ilgili sınır değerlerin belirlenmesi hususunda, yeterli çalışma bulunmamaktadır.

Zirai ilaç kullanımı konusunda, üreticiyi ye tüketiciyi bilinçlendirecek çalışmalara hız verilmeli, özellikle de sistemik etkili preparatların kullanımının kısıtlanması, yerine zorunluluk bulunduğu takdirde, kontamine etkili pestisitlerin kullanımı için öneri, destek ve yaptırımlarda bulunulmalıdır. Bilgisizce ve yerli yersiz kullanılmakta olan pestisitlerin daha ciddi kontrollerle ve bilgilendirmelerle kontrol altında tutulması önerilmektedir. Bu sonuçlar ışı̆̆ında, Üniversiteler ile Gıda, Tarım ve Hayvancılık Bakanlı̆̆ına bağlı Araştırma Enstitüleri, İl Kontrol Laboratuvarları, İl ve ilçe Müdürlüklerinin ayrıca Ziraat Odaları gibi sivil toplum kuruluşlarının koordineli olarak yapacağı hem üreticilerin hem de tüketicilerin bilgi düzeyini artıracak ve farkındalık yaratacak çalışmaların yapılması önem arz etmektedir.

\section{Teşekkür}

Öncelikle, bu çalışmanın gerçekleşmesi konusunda, 2015-HIZ-EMYO213 proje numarasıyla destek sağlayan Yüzüncü Yıl Üniversitesi Bilimsel Araştırma Projeleri Koordinatörlüğüne teşekkür ederiz. Ayrıca teknik ve cihaz desteklerinden dolayı Gıda, Tarım ve Hayvancılık Bakanlığı, Van İl Gıda Laboratuvarına da teşekkür ederiz.

\section{Kaynaklar}

Anonim (2012a). Asma Yaprağında Kalıntı ve Kodeks Değerlerinin Belirlenmesine Dair Rapor. Bağ Danışma Kurulu. Rapor No 2 Toplantı tarihi:28.3.2012.

Anonim (2012b). http://www.haberturk.com/saglik/haber/728457-en-tehlikeli-sebze-meyve-turkiyede-miuretiliyor. (Erişim tarhi: 15.07.2017). 
Anonim (2016). Gıda, Tarım ve Hayvancılık Bakanlığı, Türk Gıda Kodeksi Pestisitlerin Maksimum Kalıntı Limitleri Yönetmeliği. Resmi Gazete. Sayı: 29899. 25 Kasım 2016 (Mükerrer)

Akyıldız A, Ağçam E, Gürkan S, Çetinkaya B, Karaca E, Benli H (2014). Effects of Rinsing on Residue Level of Chlorpyrifos Ethyl, Acetamiprid and Penconazole in Grapes. Journal of Agricultural Sciences 20: 112-119.

Cabras P, Conte E, (2001). Pesticide residues in grapes and wine in Italy. Food Additives and Contaminants,18(10): 880-885.

Cangi R, Yanar Y, Yağcı A, Topçu N, Sucu S, Dülgeroğlu Y (2014). Narince Üzüm Çeşidinin Yapraklarında Farklı Fungusit Uygulamaları ve Salamura Yöntemlerine Bağlı Olarak Fungusit Kalıntı Düzeylerinin Belirlenmesi. Gaziosmanpaşa Üniversitesi Ziraat Fakültesi Dergisi JAFAG 31(2):23-30.

Çiftçioğlu G, İssa G (2006). Çevre ve Gıdalardaki Pestisit Kalıntılarının Halk Sağlığına Etkisi. İstanbul Üniv. Vet. Fak. Derg. 32 (3),91-96.

Ersoy N, Tatlı Ö, Özcan Ş, Evgil E, Coşkun L, Erdoğan E, Keskin G (2011). Üzüm ve Çilekte Pestisit Kalıntılarının Lc-Ms/Ms Ve Gc-Ms’Le Belirlenmesi. Selçuk Tarım ve Gıda Bilimleri Dergisi, 25:70-80.

Güler Ç, Çobanoğlu Z (1994). Çevresel Etkenlere Bağlı Olarak Ortaya Çıkan Hastalıklar. T, C Sağlık Bakanlığı, Çevre Sağlığı Temel Kaynak Dizisi, No:6. Ankara.

Yanar Y, Cangi R, Özata K (2015). Tokat Yöresinde Üretilen Salamuralık Asma Yapraklarında Pestisit Kalıntı düzeylerinin saptanması. Selçuk Tarım Ve Gıda Bilimleri Dergisi A, 27, 267-275.

Özdemir S (2008). Türkiye’nin Avrupa Birliği Ülkelerine Yaş Meyve-Sebze İhracatı ve Avrupa Birliği Çevre Politikalarından Kaynaklanan Teknik Engeller. Basılmamış Yüksek lisans Tezi. Çukurova Üniversitesi Fen Bilimleri Enstitüsü. Adana.

Tatlı Ö (2006). Ege Bölgesine Özgü Bazı Yaş Meyve, Sebze ve Kurutulmuş Gıda Ürünlerinde Pestisit Kalıntı Düzeylerinin Tespiti. Çukurova Üniversitesi Fen Bilimleri Enstitüsü Toprak Anabilim Dalı Yüksek Lisans Tezi, 120s.

Topuz E (2005). Tarımsal Zararlılarla Mücadelede Kimyasal Pestisitlere Alternatif Bazı. Yöntemler, Derim, 22(2): 53-59. 